\title{
Feed, energy and protein intakes of horses - A review of Finnish feeding trials
}

\author{
MARKKU SAASTAMOINEN
}

SaAstamoinen, M. T. 1993. Feed, energy and protein intakes of horses - A review of Finnish feeding trials. Agric. Sci. Finl. 2: 25-32. (Agric. Res. Centre of Finland, Equine Res. Sta., FIN-32100 Ypäjä, Finland.)

\begin{abstract}
The aim of this study was to evaluate the feed, energy and protein intakes of horses engaged in different performances by reviewing results and data concerning feed consumption in 17 feeding trials with a total 356 horses, conducted between 1972 and 1992. The dry matter intake was found to average 1.6-1.8\% of body weight for working horses and pregnant mares, and $2-3.5 \%$ for lactating mares. According to the results most of the exercising horses could be fed with energy and protein amounts currently recommended for moderate work. In Standardbred trotters, the average energy intake corresponded to the current requirements for light work. The individual variation in energy consumption among horses engaged in work of the same intensity was considerable, and seemed to be larger for Finnhorses than for warmblooded horses. The establishment of new nutrient requirements and feeding recommendations separately for trotters and riding horses of these two breeds, i.e. Finnhorses and warmblooded horses, seems justified.
\end{abstract}

Key words: feed consumption, feeding standards, nutrient requirements, nutrition

\section{Introduction}

The Finnish feeding recommendations and nutrient requirements of horses are based mainly on old feeding standards for horses used in farm work (e.g. POIJÄRVI 1938). Attempts have also been made to adapt and apply recommendations used in some other countries. A number of recommendations have been published for Finnish horse owners and breeders (e.g. AAlto 1954, SAlo et. al. 1990, PELTONEN 1988, SAASTAMOINEN 1989), as well as internationally by PELTONEN (1986) and STAUN (1990).

It may be that the current Finnish feeding recommendations misjudge the energy and protein needs of modern horses. Moreover, they ignore the differ- ences between breed and purpose of the horses (e.g. warmblooded horses vs. Finnhorses; trotter vs. saddle horse). These defects are most obvious in the case of adult exercising horses, since nutritional research in Finland has been focused mainly on brood mares and foals, while the nutrition of exercising horses has received only limited attention.

Evaluation of nutrient allowances is needed to determine the actual nutrient requirements of horses. The aim of this study, therefore, was to review the feeding data and results of a number of Finnish feeding trials in order to assess the feed, energy and protein intakes of horses engaged in different activities. These estimates were then compared to the current feeding recommendations used in Finland and in some other countries. 
Table 1. List of reviewed feeding trials.

\begin{tabular}{|c|c|c|c|c|c|}
\hline Author & $\begin{array}{l}\text { No. of } \\
\text { horses }\end{array}$ & $\begin{array}{l}\text { Breed, } \\
\text { use }\end{array}$ & $\begin{array}{l}\text { Mature } \\
\text { weight } \\
\text { kg }\end{array}$ & $\begin{array}{l}\text { Daily } \\
\text { work } \\
\text { hrs }\end{array}$ & $\begin{array}{l}\text { Basal } \\
\text { diet }\end{array}$ \\
\hline KossiL. et al. (1972) & 24 & $\mathrm{~Wb}$ rh & 557 & $1-2,, 5$ & h-o \\
\hline KossILA \& LJUNG (1977) & 22 & Wb rh & 525 & 1.85 & h-o, h-op \\
\hline Peltonen et al. (1978) & 16 & Fh tr & 525 & 1.5 & ho, h-o-gp \\
\hline KossiLA et al. (1979) & 18 & Fh pul & 550 & 1.5 & h-o, h-o-op \\
\hline SAASTAMOINEN (1983) & 14 & Wb st & 560 & 1 & h-o \\
\hline SAASTAMOINEN (unpubl.) & 20 & $\mathrm{Fh} \mathrm{h}, \mathrm{tr}$ & 530 & $1-1.5$ & h-o \\
\hline SAASTAMOINEN (unpubl.) & 20 & Fh rh, tr & 530 & $1-1.5$ & h-o \\
\hline $\begin{array}{l}\text { SAASTAMOINEN \& JUUSELA } \\
\text { (1993); JUUSELA (1989) }\end{array}$ & 40 & $\begin{array}{l}\text { Wb rh; Fh } \\
\text { rh, tr }\end{array}$ & $\begin{array}{l}561 ; \\
520,501\end{array}$ & 1 & h-o \\
\hline $\begin{array}{l}\text { SAASTAMOINEN \& HYYPPÄ } \\
\text { (unpubl.) }\end{array}$ & 18 & $\begin{array}{l}\text { Wb tr; } \\
\text { Fh tr }\end{array}$ & $\begin{array}{l}445 \\
525\end{array}$ & $0.5-0.75$ & h-o-m \\
\hline SAASTAMOINEN et al. (1992) & 30 & $\begin{array}{l}\text { Wb rh; } \\
\text { Fh rh, tr }\end{array}$ & $\begin{array}{l}573 ; \\
527,529\end{array}$ & 1.5 & h-o, h-o-hp \\
\hline Peltonen et al. (1980) & 12 & Fh br. m. & 530 & & h-o \\
\hline Peltonen (1986) & 20 & Fh br. m. & 530 & & h-o \\
\hline SAASTAMOINEN et al. (1990); & & & & & \\
\hline LÄHDEKORPI (1991) & 25 & Fh br. m. & 530 & & h-o \\
\hline Kossil_a et al. (1978) & 15 & Fh wean. & 530 & & h-o \\
\hline Peltonen et al. (1985) & 20 & Fh wean. & 530 & & h-o \\
\hline SAASTAMOINEN \& Koskinen (1993) & 22 & Fh wean. & 530 & & h-o \\
\hline SAASTAMOINEN (unpubl.) & 20 & Fh wean. & 530 & & h-o, h-cm \\
\hline Total & 356 & & & & \\
\hline
\end{tabular}

$\mathrm{Wb}=$ warmblooded; $\mathrm{Fh}=$ Finnhorse; $\mathrm{rh}=$ riding horse; $\mathrm{tr}=$ trotter; pul=load pulling; $\mathrm{st}=\mathrm{stallion}$ in performance test; br .m.=brood mare; wean=weanling; $\mathrm{h}=\mathrm{hay}$; $\mathrm{o}=\mathrm{oats}$; $\mathrm{op}=$ oats pellets; $\mathrm{gp}=$ grass pellets; $\mathrm{m}=$ molasses; $\mathrm{hp}=$ hay pellets; $\mathrm{cm}=\mathrm{concentrate}$ mixture

\section{The reviewed feeding trials}

The trials of which results and data on feed consumption were available are presented in Table 1. The trials were carried out between 1972 and 1992. A total of 356 horses were involved in the reviewed trials, representing different breeds and purposes.

Only one of these trials (KossiLA et al. 1972) had been conducted for the purpose of measuring the nutrient intake of the horses. The other trials had been made to compare various feeds, diets and nutrient levels, and the horses fed to maintain their body weight and visual body condition. The forageto-grain ratios in the trials were about 1 to $0.5-0.6$.

\section{Determination of energy and protein intakes}

Energy allowances were determined in terms of fattening feed units (FFU). Metabolizable energy (ME) values for feeds were also given in some trials, or if not, they were calculated from the digestible nutrients of the feed according to MAFF (1975). Digestible energy (DE) intakes were then converted from the ME intakes using the ME/DE ratio 0.900 (REID and WHITE 1978, VERMOREL et al. 1984, VermOREL et al. 1991) to compare the energy intakes to German and American recommendations. Protein was measured as digestible 
Table 2. Literature averages for dry matter intake $(\mathrm{kg})$ of horses $(500 \mathrm{~kg} \mathrm{bwt})$ in different performances

\begin{tabular}{ll}
\hline Warmblooded trotter & 8.0 \\
Finnhorse trotter & 8.3 \\
Warmblooded riding horse & 8.8 \\
Finnhorse riding horse & 8.1 \\
Finnhorse load pulling & 8.8 \\
Pregnant mare & $8.0-8.5$ \\
Lactating mare & $10.0-18.8$ \\
\hline
\end{tabular}

crude protein (DCP).

To obtain the energy intake required for work, the average maintenance requirements of the horses were estimated as presented by SALO et al. (1990), DLG (1984) and NRC (1989). The difference between DLG (1984) and NRC (1989), in this case, is that DLG (1984) uses metabolic weight (weight ${ }^{0.75}$ ) instead of body weight. All results in the present study are for a horse weighing $500 \mathrm{~kg}$.

\section{Results and discussion}

\section{Dry matter intake}

The variation in dry matter (DM) intake between horses in different uses was small (Table 2). The average DM intake of working horses in the reviewed trials varied from 8.0 to $8.8 \mathrm{~kg}$ per day. This is equivalent to $1.6-1.8 \%$ of the body weight and agrees with both DLG (1984) and NRC (1989). However, in Finland, this corresponds only to the recommendations for horses performing light (farm) work (POJJ̈̈RVI 1938). For pregnant and lactating mares, the DM intake in the reviewed trials was 8.0 to $8.5 \mathrm{~kg}$ and 10.0 to $18.0 \mathrm{~kg}$, respectively.

\section{Energy intake}

Work

The average daily energy intake of a $500 \mathrm{~kg}$ Standardbred trotter ( $\mathrm{n}=9$ horses) has been reported to be 5.5 FFU (80.9 MJ DE) (SAASTAMOINEN and
HYYPPÄ, unpublished). The equivalent for Finnhorse trotters $(n=50)$ can be calculated to be 6.1 FFU (89.7 MJ DE) (Peltonen et al. 1978, SAASTAMOINEN et al. 1992, SAASTAMOINEN and JuUSEla 1993, SAASTAMOINEN and HyYPPÄ, unpublished, SAASTAMOINEN, unpublished).

In Standardbred trotters, the average daily energy intake corresponds to the requirements of light work as given by SALO et al. (1990), MEYER (1992) and DLG (1984), but it was about 5\% lower than that recommended for light work by NRC (1989). In Finnhorse trotters, the average daily energy intake agrees with the requirements for moderate work given by SALO et al. (1990) and by German standards, but it was about $10 \%$ below the NRC (1989) recommendations for moderate work. In the case of Finnhorses, however, the individual daily energy intake among horses in different studies was found to vary from 5.0 to $9.5 \mathrm{FFU}$ (73-137 MJ DE), with the upper limit corresponding to the energy recommendations for intense work (SALO et al. 1990, DLG 1984, NRC 1989). It is not possible to draw any conclusions about Standardbred trotters because of their small number included in the trials.

A warmblooded riding school horse $(n=16)$ working 2 to 2.5 hours daily consumed 6.3 FFU (106.4 MJ DE) per day on an average (Kossila et al. 1972). The individual variation was about 4.8 to 8.0 FFU (81-135 MJ DE). A riding horse $(n=6)$ that was intensively ridden ("privately owned") one hour per day required 6.2 FFU (104.9 MJ DE), on an average (KossiLA et al. 1972).

In the studies of KossILA and LJUNG (1977) $(n=22)$, and JuUSELA (1989) $(n=16)$, the average energy consumption of warmblooded riding horses in regular work (education of riding instructors or light competition) was 5.7 (91.6 MJ DE) and 6.4 FFU (88.6 MJ DE) per day, respectively. The individual variation among the horses in the data of JUUSELA (1989) was about 6.0-8.0 FFU (83-111 MJ DE).

The energy intake of riding horses of the Finnhorse breed $(n=41)$ in regular work (riding teaching in groom training programme and light competition) can be estimated to average 5.7 FFU (88.1 MJ DE) per day on the basis of different studies (SAASTAMOINEN et al. 1992, SAASTAMOINEN and 
JuUSEla 1993, SAASTAMOINEN, unpublished). This corresponds to the energy requirements of warmblooded riding horses in regular work. The individual variation between horses in different trials was 4.5-9.5 FFU (67-137 MJ DE).

The average daily energy intake of young stallions during a 100-day test was 5.6 FFU (SAASTAMOINEN 1983). Work-horses of the Finnhorse breed pulling light loads consumed 5.4 FFU per day on an average (KossiLA et al. 1979).

The energy expenditure for work increased along with increased work intensity, as illustrated in Figure 1 , for which the data were adapted from JuUSELA (1989). It depended also on the use of the horse (Table 3).

For one hour of work $\left(100 \mathrm{~kg}^{-1}\right)$, an intensively ridden "privately owned" horse required more than two times the energy consumed by riding school horses and other regularly exercised horses (Table 3). Similarly, the energy required by intensively ridden horses for one hour of work was about twice that consumed by young stallions during their 100-day performance test (SAASTAMOINEN 1983). The energy consumption for one hour of work by Finnhorse riding horses was about $25 \%$ lower than the energy required by Finnhorse trotters.

The energy consumption (above maintenance) calculated per one hour of work and $100 \mathrm{~kg}$ body weight for different horse groups by type of work were in reasonable agreement with the energy expenditures reported for medium trot by DLG (1984) and for fast walk - slow trot by HINTZ et al. (1971) and PAGAN and HINTZ (1986), as well as for light to moderate work (riding horses) by MARTINROSSET (1990).

Kossila et al. (1972) reported a higher energy consumption for work by geldings than by mares. Also in the data of SAASTAMOINEN et al. (1992), the energy intake of Finnhorse stallions and geldings was somewhat higher than that of mares.

It can be assumed that most horses can be fed according to the current recommendations for moderate work. However, there was considerable individual variation in energy consumption among horses engaged in work of the same intensity. The variation was wider in Finnhorses than in warmblooded horses.

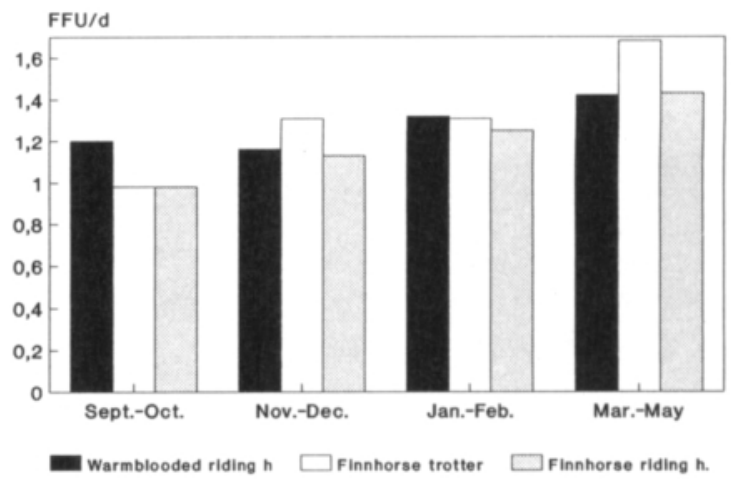

Fig. 1. The energy consumption (FFU/d) of horses (500 kg bwt) for work during the winter feeding period. Work intensity, but not amount, increased during the period. Wamblooded riding horses were ridden in a heated and Finnhorse riding horses in an unheated riding hall. Finnhorse trotters were trained outdoors (data adapted from JuUSEL.A, 1989).

\section{Pregnancy and lactation}

The average daily energy intake of pregnant mares $(n=43)$ (late pregnancy; 9-11 months of pregnancy) varied from 4.5 to $5.8 \mathrm{FFU}$ in different studies (Peltonen et al. 1980, Peltonen 1986, SAASTAMOINEN et al. 1990, LÄHDEKORPI 1991). The average daily consumption of 5.8 FFU (94.3 MJ DE) reported by LÄHDEKORPI (1991) was above that recommended by DLG (1984) and NRC (1989). The individual variation among horses in that trial was 5.2 to $7.1 \mathrm{FFU}$ (79-108 MJ DE).

PELTONEN et al. (1980) reported an average energy intake of $6.9 \mathrm{FFU}$ (123.7 MJ DE) per day $(n=12)$ during early lactation (1-2 months p.p). SAASTAMOINEN et al. (1990) measured a somewhat higher average daily energy intake, i.e. 7.6 FFU (142.9 MJ DE), during the first three months of lactation $(n=25)$. DLG (1984) recommends 120127 MJ DE and NRC (1989) 118 MJ DE for lactating mares during early lactation.

\section{Growth}

The average energy requirement of weanling foals (mature weight appr. $530 \mathrm{~kg}$ ), 6 to 12 months of age $(n=62)$, varied from 3.5 to $5.0 \mathrm{FFU}(65-75$ MJ DE) per day in different trials (PELTONEN et al. 1985, SAASTAMOINEN and KoSKINEN 1993, 
Table 3. Collection of daily energy intakes (FFU and MJ DE) above that of maintenance for mature horses (500 kg bwt) in different work (literature averages).

\begin{tabular}{|c|c|c|c|}
\hline & $\begin{array}{l}\text { Maintenance } \\
\text { requirements } \\
\text { calculated } \\
\text { according to }\end{array}$ & $\begin{array}{l}\text { Per } \\
\text { day }\end{array}$ & $\mathrm{h}^{-1}$ and $100 \mathrm{~kg}^{-1}$ \\
\hline \multirow[t]{3}{*}{ Warmblooded trotter } & & 1.0 & $0.18-0.36 \mathrm{FFU}$ \\
\hline & DLG (1984) & 17.5 & $3.2-6.4 \mathrm{MJ} \mathrm{DE}$ \\
\hline & NRC (1989) & 12.3 & $3.1-4.6 \mathrm{MJ} \mathrm{DE}$ \\
\hline \multirow[t]{3}{*}{ Finnhorse trotter } & & 1.6 & $0.22-0.32 \mathrm{FFU}$ \\
\hline & DLG (1984) & 26.3 & $3.5-5.3 \mathrm{MJ} \mathrm{DE}$ \\
\hline & NRC (1989) & 21.1 & $2.9-4.6 \mathrm{MJ} \mathrm{DE}$ \\
\hline \multirow{4}{*}{$\begin{array}{l}\text { Warmblooded riding } \\
\text { school horse }\end{array}$} & & & \\
\hline & & 1.8 & $0.14-0.18 \mathrm{FFU}$ \\
\hline & DLG (1984) & 43.0 & $3.4-4.3 \mathrm{MJ}$ DE \\
\hline & NRC (1989) & 37.8 & $3.0-3.8 \mathrm{MJ} \mathrm{DE}$ \\
\hline \multirow[t]{3}{*}{$\begin{array}{l}\text { Warmblooded riding horse } \\
\text { (education, competition) }\end{array}$} & & 1.6 & \\
\hline & DLG (1984) & 26.7 & $3.1-5.4 \mathrm{MJ} \mathrm{DE}$ \\
\hline & NRC (1989) & 21.5 & $2.5-4.1 \mathrm{MJ} \mathrm{DE}$ \\
\hline \multirow[t]{3}{*}{$\begin{array}{l}\text { Warmblooded riding horse } \\
\text { (intense riding } 1 \mathrm{~h} \text { ) }\end{array}$} & & 1.7 & $0.34 \mathrm{FFU}$ \\
\hline & DLG (1984) & 41.5 & 8.3 MJ DE \\
\hline & NRC (1989) & 36.5 & 5.1 MJ DE \\
\hline \multicolumn{4}{|l|}{ Warmblooded stallion } \\
\hline during perf. test & & 1.1 & $0.2 \mathrm{FFU}$ \\
\hline \multirow[t]{3}{*}{ Finnhorse riding horse } & & 1.2 & $0.16-0.24 \mathrm{FFU}$ \\
\hline & DLG (1984) & 24.7 & $3.3-4.9 \mathrm{MJ} \mathrm{DE}$ \\
\hline & NRC (1989) & 19.5 & $2.6-3.9 \mathrm{MJ} \mathrm{DE}$ \\
\hline Finnhorse load pulling & & 0.9 & $0.18 \mathrm{FFU}$ \\
\hline
\end{tabular}

SAASTAMOINEN, unpublished). This agrees with NRC (1989) and MARTINRosSET (1990) but is somewhat higher than that recommended by DLG (1984). Kossila et al. (1978) measured an average daily intake as high as $6.9 \mathrm{FFU}(82.1 \mathrm{MJ} \mathrm{DE})$ $(n=15)$ for weanling Finnhorse foals, which was much above the recommended energy intake for weanlings in Finland (e.g. AALTO 1954, SALO et al. 1990).

\section{Protein}

Work

The average digestible crude protein (DCP) allowance for working horses (trotters and riding horses) in the different studies was $580 \mathrm{~g}$ per day (KossILA et al. 1972, Peltonen et al. 1978, SAASTAMOINEN et al. 1992, SAASTAMOINEN and JUUSELA 1993, SAASTAMOINEN and HYYPPÄ, unpublished SAASTAMOINEN, unpublished). This was about $100 \mathrm{~g}$ more than that recommended by DLG (1984). However, ZMIJA (1991) reported for German Standardbred trotters a DCP intake of $180 \%$ of the level recommended by DLG (1984). The DCP intake per FFU varied from about 90 to $116 \mathrm{~g} / \mathrm{FFU}$ (Table 4), and was not found to differ significantly between horses in different performances.

\section{Pregnancy and lactation}

The average DCP intakes reported for pregnant mares during late pregnancy (9th-11th month) were 550-670 g per day, and 94-105 g/FFU (PELTONEN 1986, SAASTAMOINEN et al. 1990). SAASTAMOINEN et al. (1990) reported a DCP intake of $900 \mathrm{~g}$ (118 $\mathrm{g} / \mathrm{FFU})$ per day during early lactation (1-3 months 
Table 4. Literature averages for protein intakes (DCP g/FFU) of horses in different performances.

\begin{tabular}{ll}
\hline Warmblooded trotter & 94 \\
Finnhorse trotter & 95 \\
Warmblooded riding horse & $90-116$ \\
Finnhorse riding horse & 98 \\
Pregnant mare & $94-105$ \\
Lactating mare & $120-140$ \\
Weanling foal & $110-150$
\end{tabular}

p.p.) and PELTONEN et al. (1980) reported an average daily intake of $957 \mathrm{~g}$ DCP. PELTONEN (1986) suggested a minimum requirement of $700-900 \mathrm{~g}$ DCP per day during early lactation. The reported protein intakes were higher than the recommended levels in Germany (DLG 1984) for pregnancy, but somewhat lower than those for lactation.

\section{Growth}

The digestible crude protein intakes of foals (6-12 months) in different trials (Kossila et al. 1978, PELTONEN et al. 1985, SAASTAMOINEN and KOSKINEN 1993, SAASTAMOINEN, unpublished) varied from 370 to $1081 \mathrm{~g}$ (110-150 $\mathrm{g} / \mathrm{FFU})$ per day. However, it seems that an intake of 480-550 g DCP per day is adequate for normal growth of weanling foals, which agrees with DLG (1984), and that the lysine content of the diet is more important than the total protein intake (SAASTAMOINEN and KOSKINEN 1993, SAASTAMOINEN, unpublished).

\section{General discussion}

It appears that the energy and protein recommendations for adult working horses in Finland today are overestimated. This is because the old feeding recommendations, originally made for horses in farm work, are still in use. Furthermore, the individual needs of a single horse and differences between breeds and purposes of the horses are not well recognized by the horse owners.

It is particularly important to pay attention to the requirements of high performance horses. IGNA-
TOFF and HINTZ (1980) and GALlAGHER et al. (1992) in USA, and ZMJA (1991) in Germany, reported much higher $\mathrm{DE}$ and protein intakes for Standardbred trotters on race tracks than the intakes reported in the studies reviewed here. However, big differences between stables and individual horses were observed also in the U.S. and German studies.

The horses included in the reviewed trials were not on a very high performance level. Riding horses were used mainly in education or they were trained for low-level competitions (e.g. dressage in elementary classes; $100-110 \mathrm{~cm}$ obstacles). The trotters were trained mainly according to a special schedule which included slow trotting daily plus a weekly "heat" (interval) of 1000 to $2000 \mathrm{~m}$ at a speed of $1 \mathrm{~min}$. $27 \mathrm{sec}$. to $1 \mathrm{~min}$. $24 \mathrm{sec}$. per kilometre for Standardbred trotters, and $1 \mathrm{~min} .40 \mathrm{sec}$. to $2.00 \mathrm{~min}$. per kilometre for Finnhorse trotters.

However, performance depends more on the genetic potential of the horse than on its nutrition. Horses with different potentials are mainly trained with the same methods, so it can be assumed that no major differences in the feed and nutrient intakes should be expected between horses on different performance levels. Different training schedules and other environmental factors may be the reason for the considerable differences between the reviewed Finnish studies and the studies carried out on race tracks in USA and Germany.

It can be concluded that new norms for nutrient requirements and feeding standards are needed in Finland separately for trotters and riding horses of both breeds (Finnhorses, warmblooded horses). In addition, riding horses should be divided into different categories, e.g. riding school horses, competition horses and pleasure horses.

Concerning pregnant and lactating mares, the energy and protein recommendations given by PELTONEN et al. (1980) and PELTONEN (1986) and SALO et al. (1990) are still relevant and correspond to foreign recommendations.

As regards growing horses, recommendations both for outdoor housing and for traditional indoor housing are needed, because of the influence of temperature on feed consumption (CYMBALUK and CHRISTISON 1990). It seems that the current Finnish protein recommendations (in terms of digestible 
crude protein) for growing foals could be decreased by about $10-15 \%$ if the lysine intake is as high as recommended by e.g. NRC (1989).

The net energy system, on which the FFU and also the French horse feed unit (UFC) are based, is the best basis for comparison of the energy values of feedstuffs and can be considered the most suitable system in horse nutrition (e.g. MARTIN-ROSSET 1992), whereas the digestible energy (DE) system, overestimates the energy values of feeds. The maintenance FFU requirement (SALO et al. 1990) calculated per kilogram of metabolic weight equals the French horse feed unit (UFC) requirement for maintenance.

The energy requirements of exercising horses seem to be more efficiently determined per one hour of work than per day, because there is more variation in the amount of daily activity and work than, e.g., in the training methods and training intensity in a particular horse group. However, it is complicated to determine the energy requirements for work because there are so many factors affecting these requirements. In addition to work intensity, factors such as terrain, type of ground surface, and ability of the rider affect the energy expenditure of a horse. Feeds and their combination in the diet, as well as the breed and sex of the horse, also may have an influence on energy consumption. Furthermore, climatic conditions, especially temperature and wind velocity, have been found to affect the energy consumption of a horse (PAGAN and HINTZ 1986, CymbaluK and Christison 1990). Thus, more research is needed before new recommendations can be established. It is also important to utilize all available data from practical conditions in determining the recommendations.

\section{References}

Aalto, O. 1954. On feeding of foals. (In Finnish - English summary). Maatalous ja koetoiminta VIII. 8 p.

Crmbaluk, N.F. \& Christison, G.I. 1990. Environmental effects on thermoregulation and nutrition of horses. In: Hintz, H.F. (ed.). The veterinary clinics of North America. Equine Practice. Clinical nutrition. vol 6, 2: 355-372.

DLG 1984. DLG-Futterwerttabellen für Pferde. 2. Auflage. DLG-Verlag, Frankfurt am Main. 122 p.

Gallagher, K., Leech, J. \& Stowe, H. 1992. Protein, energy and dry matter consumption by racing standardbreds: $\mathrm{A}$ field survey. J. Equine Vet. Sci. 12: 382-388.

Hintz, H. F., Roberts, S. J., SAbin, S. W. \& Schryver, H. F. 1971. Energy requirements of light horses for various activities. J. Anim. Sci. 32: 100-102.

IgNATOFF, J. \& Hintz, H. F. 1980. A survey of feeding practices at two Standardbred racetracks. Feedstuff 52: 24-25.

JuUSEl_A, J. 1989. Vitamiinitäydennykset hevosten ruokinnassa. (M. Sci. Thesis.) 76 p.

Kossila, V., Heı́кіL.Ä, T. \& TupamÄKı. A. 1979. Whole oat plant pellets as a sole source of diet for horses. Paper. 30. Ann. Meet. of Eur. Assoc. for Anim. Prod.

-, Lillikvist, A., Virtanen, E., TanhuanpäÄ, E. \& Rauvala. L. 1978. Blood and hair composition of Finnfoals. Paper. 29. Ann. Meet of Eur. Assoc. for Anim. Prod.

— \& LJUNG, G. 1977. Value of whole plant pellets in horse feeding. Ann. Agric. Fenn. 15: 316-321.

-, Virtanen, E \& Maukonen, J. 1972. Hay-oat diet as a source of energy, digestible crude protein, minerals and trace elements for saddle horses. (In Finnish - English abstract). J. Sci. Agr. Soc. Finl. 44: 217-227.

LÄHDEKORPI, M. 1991. Ruokinnan kupari- ja sinkkitason vaikutus varsan kasvuun ja luuston kehitykseen. (M. Sci.
Thesis.) 95 p.

MAFF 1975. Energy allowances and feeding systems for ruminants. Ministry of Agriculture, Fisheries and Food. Technical Bulletin 33. London. 9 p.

MArTin-Rosset, W. (ed.). 1990. L'alimentation des chevaux. Techniques et pratiques. INRA. Paris. 232 p.

- 1992. Nutrient requirements and allowances for energy and protein in horses. Paper. 43. Ann. Meet. of Eur. Assoc. for Anim. Prod.

Meyer, H. 1992. Pferdefütterung. 2. Auflage. Paul Parey, Berlin und Hamburg. 223 p.

NRC 1989. Nutrient requirements of horses. National Academy Press, Washington D.C. 100 p.

Pagan, J. D. \& Hintz, H. F. 1986. Equine energetics. II. Energy expenditure in horses during submaximal exercise. J. Anim. Sci. 63: 822-830.

Peltonen, T. 1986. Nitrogen level and allowances in pregnancy and lactation. Paper, 37th Ann. Meet. of Eur. Assoc. for Anim. Prod.

- 1988. Hevosen ruokinta. In: Hevostalouden laskelmia. Suomen Hippos, Helsinki. p. 3-21.

-, Alttalo, I., Koskinen, E. \& Juga, J. 1985. Varsojen kasvukoe. Mimeogr. Maataloustieteen päivät 1985, Helsinki.

—, Kossila, V., Antil.a. V. \& Huida, L. 1980. Effect of protein supplement on milk composition of mares and growth rate of their foals. Paper. 31. Ann. Meet. of Eur. Assoc. for Anim. Prod.

—, Kossila, V., Syruälä, L. \& Immonen I, 1978. Feeding value of grass molasses pellets and their influence on the faecal microbiota of horses. Ann. Agric. Fenn. 17:109114. 
PoIJÄrVI, I. 1938. Tuloksia hevosten ruokintakokeista. Valtion maatalouskoetoiminnan tiedonantoja No. 154. 27 p.

ReID, J. T. \& Whrte, O. D. 1978. Comparative energetic efficiency of farm animals. Univ. of. Arkansas Agr. Exp. Sta. Special Rep. 72.

SaAstamoinen, M. 1983. Stallion performance test in 1983. (In Finnish). Jäsenlehti 3/83: 7-8, Ratsujalostusliitto.

- 1989. Feeding of riding horses. (In Finnish). In: Hevosmuistio. Ratsastuskustannus Oy, Helsinki. p. 95-97.

— \& Juusel.A, J. 1993. Serum vitamin E concentration of horses on different vitamin E supplementation levels. Acta Agric. Scand., Sect. A, Animal Sci. 43:52-57.

— \& Koskinen, E. 1993. Influence of quality of dietary protein supplement and anabolic steroids on muscular and skeletal growth of foals. Anim. Prod. 56:135-144

—, LÄHDEKorPI, M. \& HyYPPÄ, S. 1990. Copper and zinc levels in the diet of pregnant and lactating mares. Paper. 41 st Ann. Meet. of Eur. Assoc. for Anim. Prod.

-, Manninen, M. \& Rantanen, A. 1992. Compounded pelleted fibre feed and hay pellets as substitutes for hay in horse feeding. Agric. Sci. Finl. 1: 225-232.

SAlo, M.-L., TuOri, M. \& Kinskinen, T. 1990. Rehutaulukot ja ruokintanormit. Helsinki. 70 p.
STAUN, H. 1990. Energy and nitrogen systems used in northern Europe for estimating and expressing value of feedstuffs in horse. Paper. 41st Ann. Meet. of Eur. Assoc. for Anim. Prod.

Vermorel, M., Jarrige, R. \& MartinRosset, W. 1984. Metabolisme et besoins energetiques du cheval, le systeme des UFC. In: Le Cheval, Reproduction, Selection, Alimentation, Exploitation. I.N.R.A. Paris, p. 239-276.

-, Martin-Rosset, W. \& Vernet, J. 1991. Energy utilization of two diets for maintenance by horses; agreement with the new French net energy system. J. Vet. Sci. 11: 33-35.

ZMUA, G. 1991. Fütterungspraxis bei Galopp- und Trabrennpferden. Thesis. Tierärztliche Hochschule Hannover. $79 \mathrm{p}$.

Manuscript received December 1992

Markku Saastamoinen

Agricultural Research Centre of Finland

Equine Research Station

FIN-32100 Ypäjä, Finland

\title{
SELOSTUS
}

\section{Hevosen rehun syönti sekä energian ja valkuaisen saanti arvioituna suomalaisten ruokintakoetulosten perusteella}

\author{
MARKKU SAASTAMOINEN \\ Maatalouden tutkimuskeskus
}

Hevosen rehun, energian ja valkuaisen saanti arvioitiin 17 suomalaisen ruokintakokeen tulosten ja rehunkulutustietojen perusteella. Kokeet oli tehty vuosien 1972 ja 1992 välisenä aikana, ja niissä oli ollut mukana yhteensä 356 eri ikäistä ja erilaisessa käytössä ollutta hevosta. Urheiluhevoset ja kantavat tammat söivät rehun kuiva-ainetta keskimäärin 1,6-1,8 \% elopainostaan. Imettävien tammojen kuiva-aineen syönti oli keskimäärin 2-3,5 \% niiden elopainosta. Samanlaisessa rasi- tuksessa olevien hevosten energiankulutuksessa esiintyi suurta yksilöllistä vaihtelua. Vaihtelu oli suurempaa suomenhevosilla kuin lämminverisillä. Tulosten mukaan suurin osa aikuisista urheiluhevosista voidaan ruokkia nykyisten keskiraskaan työn normien mukaisesti, mutta uudet ruokintasuositukset erikseen ratsu- ja ravihevosille ovat tarpeen. Suosituksissa on otettava huomioon myös rotujen väliset erot. 